\title{
Association of VAMP-2 and Syntaxin 1A Genes with Adult Attention Deficit Hyperactivity Disorder
}

\author{
Aye Nur Inci Kenar ${ }^{1}$, Özlem İzci Ay², Hasan Herken ${ }^{3 凶}$, and Mehmet Emin Erdal ${ }^{2}$ \\ ${ }^{1}$ Psychiatry Clinic, Denizli State Hospital, Denizli, Turkey \\ ${ }^{2}$ Department of Medical Biology and Genetics, School of Medicine, Mersin University, Turkey \\ ${ }^{3}$ Department of Psychiatry, School of Medicine, Pamukkale University, Denizli, Turkey
}

\begin{abstract}
Objective The etiology of attention deficit hyperactivity disorder (ADHD) has not been entirely clarified yet. Structural and metabolic differences at the prefrontal striatal cerebellary system and the interaction of gene and environment are the main factors that thought to play roles in the etiology. Genetic investigations are performed especially about the dopamine pathways and receptors. In this study; it was aimed to investigate the association of the synaptobrevin-2 (VAMP-2) gene Ins/Del polymorphism and syntaxin $1 \mathrm{~A}$ gene intron 7 polymorphism, which take place in encoding presynaptic protein, with adult ADHD.

Methods One hundred thirty-nine patients, having ADHD aging between 18 and 60 years and 106 healthy people as controls were included into the study. DNA samples were extracted from whole blood and genetic analysis were performed.

Results A significant difference was determined between ADHD and VAMP-2 Ins/Del polymorphism and syntaxin $1 \mathrm{~A}$ intron 7 polymorphism according to the control group. These polymorphisms were found not to be associated with subtypes of ADHD.

Conclusion It is supposed that synaptic protein genes together with dopaminergic genes might have roles in the etiology of ADHD.
\end{abstract}

Psychiatry Investig 2014;11:76-83

Key Words ADHD, VAMP-2, Synaptobrevin 2, Syntaxin 1A, Genetic.

\section{INTRODUCTION}

The etiology of attention deficit hyperactivity disorder (ADHD) is not completely understood, but it is well known that the genetic transmission is an important factor in ADHD etiology. ${ }^{1}$ In particular, it is supposed to be a complex psychiatric disorder which also involves the interaction of gene and environment. ${ }^{2}$ Despite the studies reporting association between $\mathrm{ADHD}$ and serotonergic system, genes of dopaminergic system are the mostly blamed system genes among the genetic factors. ${ }^{3,4}$ However, recently, researchers suppose that the problem at the synaptic gap is not only limited to the dopamine, but also there may be problems in the modulation of neurotransmitter releasing and synaptogene-

Received: February 11, 2013 Revised: May 6, 2013

Accepted: June 2, 2013 Available online: January 21, 2014

$\triangle$ Correspondence: Hasan Herken, MD

Department of Psychiatry, School of Medicine, Pamukkale University, Çamlaraltı Street, Kınıklı 20070, Denizli, Turkey

Tel: +90-258-4440728, Fax: +90-258-2131034, E-mail: hherken@pau.edu.tr

(a) This is an Open Access article distributed under the terms of the Creative Commons Attribution Non-Commercial License (http://creativecommons.org/licenses/bync/3.0) which permits unrestricted non-commercial use, distribution, and reproduction in any medium, provided the original work is properly cited. sis, and they targetted their efforts towards the genes encoding presynaptic proteins having roles in those processes. ${ }^{5}$

Vesicle-associated membrane protein 2 (VAMP2) (synaptobrevin 2) and syntaxin $1 \mathrm{~A}$ along with The synaptosomalassociated protein, $25 \mathrm{kDa}$ (SNAP-25) protein compose SNARE proteins that have roles in the modulation of neurotransmitter releasing. ${ }^{6}$ Among these genes, the most frequently studied one is SNAP-25 gene and the relation between ADHD and two polymorphisms of (MnlI, DdeI) this gene was investigated in many studies. A relation between either or both DdeI and MnlI polymorphisms are found to be related with $\mathrm{ADHD} .^{7-9} \mathrm{~A}$ relation between $\mathrm{ADHD}$ and SNAP-25 MnlI polymorphism was determined in a study which was performed in our country, Turkey. ${ }^{10}$ In another study from Turkey, the changes in the brain bloodstream with single dose of psychostimulant in ADHD subjects were analyzed and they reported that brain bloodstream may be affected by SNAP-25 polymorphism after psychostimulant therapy. ${ }^{11}$ All these studies have brought up the other proteins that have roles in the same function along with SNAP25. However, no study was noticed investigating the relation between VAMP2 and syntaxin 1A genes and ADHD in the 
literature. Yet, there are some studies investigating the relation between VAMP2 and syntaxin 1A genes and various psychiatric disorders that the modulation of neurotransmitter releasing is important in their etiopathogenesis.

No relation was obtained between the gene polymorphisms of SNARE proteins; VAMP2, syntaxin 1A and SNAP25 and schizophrenia. ${ }^{12}$ No relation was obtained between VAMP2 gene and bipolar disease, which has a comorbid diagnosis rate of $9.5 \%$ with $\mathrm{ADHD}$, in a study that was performed among bipolar patients. ${ }^{13,14}$

While no relation was determined between schizophrenia and exon 3 polymorphism of syntaxin 1A gene, a relation was reported between schizophrenia and intron $7 \mathrm{~T}>\mathrm{C}$ polymorphism of syntaxin $1 \mathrm{~A}$ gene. ${ }^{15}$ In the post-mortem brain studies of the schizophrenia patients, higher levels of syntaxin $1 \mathrm{~A}$ in cingulat cortices and higher levels of syntaxin $1 \mathrm{~A} \mathrm{m-}$ RNA in temporal cortices with respect to the control subjects were determined. ${ }^{16,17}$ Bartl et al. ${ }^{18}$ reported that they observed reduction in the syntaxin $1 \mathrm{~A} \mathrm{m-RNA} \mathrm{levels} \mathrm{and} \mathrm{down-regu-}$ lation in synaptic proteins after administration of methylphenidate $(\mathrm{MPH})$ in a study which they have investigated the effects of MPH, currently used in the treatment of ADHD.

In this study, we aimed to investigate the relation between VAMP-2 and syntaxin 1A genes, which have roles in encoding presynaptic proteins, and ADHD.

\section{METHODS}

\section{Subjects}

A total of 139 patients between ages of 18 and 60, meeting DSM-IV criteria for adult ADHD were included into the study. The control group consisted of 106 healthy subjects between ages of 18 and 60. All participants were recruited from the research center and were of Turkish origin. A written consent to participate in the study was obtained from the subjects after they were thoroughly informed about the research details. Approval of the study was given by the ethics committee of the Pamukkale University. Comorbid psychiatric disorders in ADHD and the control group were evaluated with Structured Clinical Interview For DSM-IV Axis I Disorders (SCID I) ve Structured Clinical Interview For DSMIIIR Personality Disorders (SCID II). Exclusion criteria were psychotic disorder, severe neurological comorbidity, epilepsy, mental retardation and unliterate in ADHD and control groups. Patients were evaluated with Wender Utah Rating Scale (WURS) and Adult Attention Deficit Hyperactivity Disorder Diagnosis and Evaluation Scale. Patients, who scored 36 points or more on the WURS and answered at least 6 of 9 questions as 2 or 3 of first and second parts of
Adult Attention Deficit Hyperactivity Disorder Diagnosis and Evaluation Scale were diagnosed as ADHD. The control group was also evaluated with WURS and Adult Attention Deficit Hyperactivity Disorder Diagnosis and Evaluation Scale and subjects who met adult ADHD criteria were excluded from the control group.

\section{Instruments}

\section{Social demographic data form}

A data sheet developed by the researchers for studying socio-demographic characteristics of study groups.

\section{Wender-Utah Rating Scale (WURS)}

This scale can be used to assess adults for Attention Deficit Hyperactivity Disorder with a subset of 25 questions associated with that diagnosis. WURS was developed by Ward and Wender in $1993 .{ }^{19}$ Turkish validity and reliability of WURS was established by Oncü et al. ${ }^{20}$ and the cut-off score point was 36.

\section{Adult ADD/ADHD DSM IV-Based Diagnostic Screening and Rating Scale}

Adult Attention Deficit Hyperactivity Disorder Diagnosis and Evaluation Scale were developed by Turgay in 1995. It is a self assessment scale and patients can complete the questionnaire after being duly informed. When developing adult $\mathrm{ADD} / \mathrm{ADHD}$ Scale, 18 symptoms of the diagnostic criteria in DSM-IV were reframed, so patients can understand them. Turkish validity and reliability was established by Gunay and colleagues. $^{21}$

\section{Structured Clinical Interview For DSM-IV Axis I Disorders (SCID I)}

It is a semi-structured interview for making the major DSM-IV Axis I diagnoses. ${ }^{22}$

\section{Structured Clinical Interview For DSM-IIIR Personality Disorders (SCID II) \\ It is a semi-structured interview for making DSM-IV Axis II: Personality Disorder diagnoses. ${ }^{23}$}

\section{DNA Isolation and Molecular Analysis}

For the amplification of VAMP 2 gene 26 bp Ins/Del polymorphism, DNA was isolated from peripheral blood leukocytes by standard phenol/chloroform method and genotyped by polymerase chain reaction (PCR) method. PCR was performed with a personal thermal cycler (Techgene, NJ, USA), using VAMP2 F-5'-ACAAAGTGCGCCTTATACGC-3'/ VAMP2 R-5'-GATTTTCCTTGACGACACTC-3' primers. 
For the amplification of Syntaxin 1A gene intron 7 polymorphism (rs35459363), DNA was isolated from peripheral blood leukocytes by standard phenol/chloroform method and genotyped by polymerase chain reaction-restriction fragment length polymorphism (PCR-RFLP) method. PCR was performed with a personal thermal cycler (Techgene, NJ, USA), using STAX2 F-5'-CAATGCTGCTGCTGAACTC-3'/ STAX2 R-5'-CGCTGACATTTATGTGACC-3' primers.

\section{Statistical analysis}

Statistical Package for the Social Sciences (SPSS) version 10.0 for Windows computing program was used for statistical analysis of the data. Chi-square test was used to compare categorical variables and independent samples t test was used to compare continuous variables. Logistic regression analysis was used to assess the risk. A p value of $<0.05$ was accepted statistically significant.

\section{RESULTS}

A total of 139 patients with adult ADHD and 106 healthy controls were included into the study. Mean age of the study group was $27.12 \pm 9.77$ and mean age of the control group was $27.86 \pm 7.88$. There was no significant difference between study and control groups regarding age ( $>>0.05)$. The study group consisted of 61 women (43.9\%) and 78 men (56.1\%) and the control group consisted of 41 women (38.7\%) and 65 men (61.3\%). There was also no significant difference between study and control groups regarding gender $(\mathrm{p}>0.05)$. Frequencies of comorbid psychiatric disorder diagnoses and results of WURS and adult ADHD rating scale scores in $\mathrm{ADHD}$ and the control groups were shown in Table 1 and 2.

Of the 139 patients with adult ADHD, 40 (28.8\%) were diagnosed as predominantly inattentive type, 39 (28.1\%) were diagnosed as predominantly hyperactive-impulsive type and 60 (43.2\%) were diagnosed as combined type of ADHD.

\section{VAMP 2 gene results of the groups}

Because of technical problems, genomic DNAs for the VAMP 2 gene could not be obtained from 5 of the 139 patients and 7 of the 106 control subjects, and they were not included into the genotype distribution and allele frequency results for this gene.

When frequencies of VAMP 2 Ins/Del polymorphism genotypes were compared according to gender, no statistically significant difference was found between the genders in

Table 1. Frequencies of comorbid psychiatric disorder diagnoses

\begin{tabular}{|c|c|c|c|}
\hline & ADHD & Control & Total \\
\hline \multicolumn{4}{|l|}{ SCID I } \\
\hline No comorbidity & $48(32.9 \%)$ & $98(67.1 \%)$ & $146(100.0 \%)$ \\
\hline Depressive disorders & $39(97.5 \%)$ & $1(2.5 \%)$ & $40(100.0 \%)$ \\
\hline Panic disorders & $1(100.0 \%)$ & $0(0 \%)$ & $1(100.0 \%)$ \\
\hline OCD & $6(85.7 \%)$ & $1(14.3 \%)$ & $7(100.0 \%)$ \\
\hline GAD & $23(100.0 \%)$ & $0(0 \%)$ & $23(100.0 \%)$ \\
\hline Bipolar disorders & $9(90.0 \%)$ & $1(10.0 \%)$ & $10(100.0 \%)$ \\
\hline Somatoform disorders & $2(100.0 \%)$ & $0(0 \%)$ & $2(100.0 \%)$ \\
\hline Social phobia & $3(75.0 \%)$ & $1(25.0 \%)$ & $4(100.0 \%)$ \\
\hline Adjustment disorders & $8(66.7 \%)$ & $4(33.3 \%)$ & $12(100.0 \%)$ \\
\hline Total & $139(56.7 \%)$ & $106(43.3 \%)$ & $245(100.0 \%)$ \\
\hline \multicolumn{4}{|l|}{ SCID II } \\
\hline No comorbidity & $92(49.2 \%)$ & $95(50.8 \%)$ & $187(100.0 \%)$ \\
\hline OCPD & $7(70.0 \%)$ & $3(30.0 \%)$ & $10(100.0 \%)$ \\
\hline Avoidant PD & $2(33.3 \%)$ & $4(66.7 \%)$ & $6(100.0 \%)$ \\
\hline Borderline PD & $16(94.1 \%)$ & $1(5.9 \%)$ & $17(100.0 \%)$ \\
\hline Narcissistic PD & $3(100.0 \%)$ & $0(0 \%)$ & $3(100.0 \%)$ \\
\hline Histrionic PD & $4(80.0 \%)$ & $1(20.0 \%)$ & $5(100.0 \%)$ \\
\hline Self defeating PD & $5(71.4 \%)$ & $2(28.6 \%)$ & $7(100.0 \%)$ \\
\hline Antisocial PD & $10(100.0 \%)$ & $0(0 \%)$ & $10(100.0 \%)$ \\
\hline Total & $139(56.7 \%)$ & $106(43.3 \%)$ & $245(100.0 \%)$ \\
\hline
\end{tabular}

ADHD: attention deficit hyperactivity disorder, SCID: Structured Clinical Interview for DSM-IV, OCD: obsessive compulsive disorder, GAD: generalized anxiety disorder, OCPD: obsessive compulsive personality dosirder, PD: panic disorder 
both ADHD and the control group ( $\mathrm{p}>0.05$ ) (Table 3 ).

When the groups were compared according to VAMP 2 gene $26 \mathrm{bp}$ Ins/Del polymorphism allele frequencies; in ADHD group, Ins allele (patient: $83.2 \%$, control: $70.2 \%$ ) and in the control group, Del allele (patient: $16.8 \%$, control: $29.8 \%$ ) was determined more often and the difference between the groups was found statistically significant $(p=0.001)$. When the groups were compared according to genotype frequencies; in ADHD group, $69.4 \%$ of them had Ins/Ins genotype, $27.6 \%$ of them had Ins/Del genotype, 3.0\% of them had Del/Del genotype and in the control group, $42.4 \%$ of them had Ins/Ins genotype, $55.6 \%$ of them had Ins/ Del genotype and $2.0 \%$ of them had Del/Del genotype. The difference between the groups was found statistically signifi-

Table 2. Results of WURS and Adult ADD/ADHD Scale scores

\begin{tabular}{lcc}
\hline \multicolumn{1}{c}{ Scale } & Mean* & SD \\
\hline WURS & 47.14 & 14.27 \\
ADHD & 19.31 & 11.21 \\
Control & & \\
Inattention symptoms & 5.65 & 2.32 \\
ADHD & 1.04 & 1.61 \\
Control & & \\
Inattention points & 15.49 & 5.37 \\
ADHD & 6.55 & 3.84 \\
Control & & \\
Hyperactivity/impulsivity symptoms & 6.10 & 2.03 \\
ADHD & 1.49 & 1.67 \\
Control & & \\
Hyperactivity/impulsivity points & 16.82 & 4.98 \\
ADHD & 6.33 & 4.52 \\
Control &
\end{tabular}

*t-test was performed. WURS: Wender-Utah Rating Scale, Adult ADD/ADHD Scale: Adult Attention Deficit Hyperactivity Disorder Diagnosis and Evaluation Scale, ADHD: attention deficit hyperactivity disorder cant $(\mathrm{p}<0.001)$.

Ins allele was determined in $97.0 \%$ of $\mathrm{ADHD}$ group and in $98.0 \%$ of the control group and there was no significant difference between the groups ( $p>0.05$ ). When the groups were compared with respect to the Del allele, ADHD group and the control group were found to have statistically significantly different $(\mathrm{p}<0.001)$ rates of Del allele which were $30.6 \%$ and $57.6 \%$ respectively (Table 4 ).

When Ins/Ins and Ins/Del genotypes of VAMP 2 gene Ins/ Del polymorphism were compared, the rate of Ins/Ins genotype was higher (71.5\%) in ADHD group and the rate of Ins/ Del genotype was higher $(56.7 \%)$ in the control group $(\mathrm{p}<0.001)$. When Ins/Ins and Del/Del genotypes and Ins/Del and Del/Del genotypes were compared with each other, no significant difference was determined ( $p>0.05)$.

In the logistic regression analysis, when Ins/Del genotype was regarded as reference, the possibility of having Ins/Ins genotype in the subjects diagnosed as ADHD is 3 times

Table 4. Frequencies of VAMP 2 gene Ins/Del polymorphism

\begin{tabular}{|c|c|c|c|}
\hline & $\mathrm{ADHD}, \mathrm{n}(\%)$ & Control, n (\%) & p value* \\
\hline \multicolumn{3}{|l|}{ Allele frequencies } & $0.001^{* *}$ \\
\hline Ins & $223(83.2)$ & $139(70.2)$ & \\
\hline Del & $45(16.8)$ & $59(29.8)$ & \\
\hline Total & $268(100.0)$ & $198(100.0)$ & \\
\hline \multicolumn{3}{|l|}{ Genotype frequencies } & $0.000^{* *}$ \\
\hline Ins/Ins & $93(69.4)$ & $42(42.4)$ & \\
\hline Ins/Del & $37(27.6)$ & $55(55.6)$ & \\
\hline Del/Del & $4(3.0)$ & $2(2.0)$ & \\
\hline Total & $134(100.0)$ & $99(100.0)$ & \\
\hline \multicolumn{4}{|c|}{ Presence or absence of Ins and Del alleles } \\
\hline Ins/Ins+Insl/Del & $130(97.0)$ & $97(98.0)$ & 1.000 \\
\hline Del/Del+Ins/Del & $41(30.6)$ & $57(57.6)$ & $0.000^{* *}$ \\
\hline
\end{tabular}

${ }^{*}$ chi-square test was performed, ${ }^{* *} \mathrm{p}<0.05$. VAMP 2 : vesicle-associated membrane protein 2, ADHD: attention deficit hyperactivity disorder

Table 3. Frequencies of VAMP 2 Ins/Del polymorphism genotypes according to genders

\begin{tabular}{|c|c|c|c|c|c|}
\hline & \multicolumn{3}{|c|}{ VAMP 2 gene } & \multirow{2}{*}{ Total } & \multirow{2}{*}{ p value* } \\
\hline & Ins/Ins & Ins/Del & Del/Del & & \\
\hline ADHD & & & & & 0.324 \\
\hline Female & $38(64.4 \%)$ & $18(30.5 \%)$ & $3(5.1 \%)$ & $59(100.0 \%)$ & \\
\hline Male & $55(73.3 \%)$ & $19(25.3 \%)$ & $1(1.3 \%)$ & $75(100.0 \%)$ & \\
\hline Total & $93(69.4 \%)$ & 37 (27.6\%) & $4(3.0 \%)$ & $134(100.0 \%)$ & \\
\hline Control & & & & & 0.442 \\
\hline Female & $18(50.0 \%)$ & $17(47.2 \%)$ & $1(2.8 \%)$ & $36(100.0 \%)$ & \\
\hline Male & $24(38.1 \%)$ & $38(60.3 \%)$ & $1(1.6 \%)$ & $63(100.0 \%)$ & \\
\hline Total & $42(42.4 \%)$ & $55(55.6 \%)$ & $2(2.0 \%)$ & $99(100.0 \%)$ & \\
\hline
\end{tabular}

*chi-square test was performed. VAMP 2: vesicle-associated membrane protein 2, ADHD: attention deficit hyperactivity disorder 
higher than the subjects that are not ADHD ( $<<0.001,95 \%$ CI: 1.637-5.362). When Ins/Ins genotype was regarded as reference, the possibility of having Ins/Del genotype in the subjects that are not $\mathrm{ADHD}$ is $40 \%$ higher than the subjects diagnosed as ADHD ( $\mathrm{p}<0.001,95 \% \mathrm{CI}$ : 0.186-0.611). The possibility of having Ins allele in the subjects diagnosed as $\mathrm{ADHD}$ is 2 times higher than the subjects that are not $\operatorname{ADHD}(\mathrm{p}=0.011,95 \%$ CI: 1.166-3.283).

When ADHD subtypes and genotype distributions were compared, Ins/Ins genotype was found the most often in the predominantly inattentive type $(74.4 \%)$ and Ins/Del genotype was found the most often in the combined type (31.0\%). The difference between the subtypes was not found statistically significant $(\mathrm{p}>0.05)$.

\section{Syntaxin 1A gene intron 7 polymorphism results of the groups}

Because of technical problems, genomic DNAs for the Syntaxin 1A gene could not be obtained from 5 of the 139 patients and 8 of the 106 control subjects, and they were not included into the genotype distribution and allele frequency results for this gene.

In $\mathrm{ADHD}$ group, when frequencies of Syntaxin $1 \mathrm{~A}$ gene intron 7 polymorphism genotypes were compared according to gender; genotype frequency among females was as follows: $8.5 \% \mathrm{~T} / \mathrm{T}$ genotype, $69.5 \% \mathrm{~T} / \mathrm{C}$ genotype, $22.0 \% \mathrm{C} / \mathrm{C}$ genotype, and among males was as follows: $20.0 \% \mathrm{~T} / \mathrm{T}$ genotype, $46.7 \%$ T/C genotype, $33.3 \% \mathrm{C} / \mathrm{C}$ genotype. The difference between the genders was found statistically significant $(\mathrm{p}=0.024)$. In the control group, no statistically significant difference was found between the genders ( $p>0.05$ ) (Table 5).

When the groups were compared according to Syntaxin 1A gene intron 7 polymorphism allele frequencies; in ADHD group, T allele (patient: $43.3 \%$, control: $24.5 \%$ ) and in the control group, C allele (patient: $56.7 \%$, control: $75.5 \%$ ) was determined more often and the difference between the groups was found statistically significant $(\mathrm{p}<0.001)$. When the groups were compared according to genotype frequencies; in ADHD group, $14.9 \%$ of them had T/T genotype, $56.7 \%$ of them had T/C genotype, $28.4 \%$ of them had $\mathrm{C} / \mathrm{C}$ genotype and in the control group, $6.1 \%$ of them had $\mathrm{T} / \mathrm{T}$ genotype, $36.7 \%$ of them had $\mathrm{T} / \mathrm{C}$ genotype and $57.1 \%$ of them had $\mathrm{C} / \mathrm{C}$ genotype. The difference between the groups was found statistically significant $(\mathrm{p}<0.001)$.

$\mathrm{T}$ allele was determined in $71.6 \%$ of the ADHD group and in $42.9 \%$ of the control group, and $\mathrm{C}$ allele was determined in $85.1 \%$ of the ADHD group and in $93.9 \%$ of the control group and the difference between the groups was found statistically significant (respectively $\mathrm{p}<0.001, \mathrm{p}=0.036$ ) (Table 6).

When T/T and C/C genotypes of Syntaxin 1A gene intron 7 polymorphism were compared with each other, T/T genotype was found statistically significantly higher (34.5\%) in $\mathrm{ADHD}$ group and $\mathrm{C} / \mathrm{C}$ genotype was found significantly higher $(90.3 \%)$ in the control group $(\mathrm{p}<0.001)$. Yet, when T/

Table 6. Frequencies of Syntaxin $1 \mathrm{~A}$ gene intron 7 polymorphism

\begin{tabular}{lccc}
\hline & ADHD, $\mathrm{n}(\%)$ & Control, $\mathrm{n}(\%)$ & $\mathrm{p}$ value* \\
\hline Allele frequencies & & & $0.000^{* *}$ \\
$\mathrm{~T}$ & $116(43.3)$ & $48(24.5)$ & \\
$\mathrm{C}$ & $152(56.7)$ & $148(75.5)$ & \\
Total & $268(100.0)$ & $196(100.0)$ &
\end{tabular}

Genotype frequencies

$\mathrm{T} / \mathrm{T} \quad 20(14.9) \quad 6(6.1)$

$\mathrm{T} / \mathrm{C} \quad 76(56.7) \quad 36(36.7)$

$\mathrm{C} / \mathrm{C} \quad 38(28.4) \quad 56(57.1)$

Total $134(100.0) \quad 98(100.0)$

Presence or absence of $\mathrm{T}$ and $\mathrm{C}$ alleles

\begin{tabular}{rrrr}
$\mathrm{T} / \mathrm{T}+\mathrm{T} / \mathrm{C}$ & $96(71.6)$ & $42(42.9)$ & $0.000^{* *}$ \\
$\mathrm{C} / \mathrm{C}+\mathrm{T} / \mathrm{C}$ & $114(85.1)$ & $92(93.9)$ & $0.036^{* *}$ \\
\hline
\end{tabular}

${ }^{*}$ chi-square test was performed, ${ }^{* *} \mathrm{p}<0.05$. ADHD: attention deficit hyperactivity disorder

Table 5. Frequencies of STX $1 \mathrm{~A}$ intron 7 polymorphism genotypes according to genders

\begin{tabular}{ccccc}
\hline & \multicolumn{3}{c}{ STX 1A Gene } & Total \\
\cline { 2 - 4 } ADHD & T/T & T/C & C/C & \\
Female & $5(8.5 \%)$ & $41(69.5 \%)$ & $13(22.0 \%)$ & $59(100.0 \%)$ \\
Male & $15(20.0 \%)$ & $35(46.7 \%)$ & $25(33.3 \%)$ & $75(100.0 \%)$ \\
Total & $20(14.9 \%)$ & $76(56.7 \%)$ & $38(28.4 \%)$ & $134(100.0 \%)$ \\
Control & & & & $36(100.0 \%)$ \\
Female & $1(2.8 \%)$ & $17(47.2 \%)$ & $18(50.0 \%)$ & 6.197 \\
Male & $5(8.1 \%)$ & $19(30.6 \%)$ & $38(61.3 \%)$ & $62(100.0 \%)$ \\
Total & $6(6.1 \%)$ & $36(36.7 \%)$ & $56(57.1 \%)$ & $98(100.0 \%)$ \\
\hline
\end{tabular}

${ }^{*}$ chi-square test was performed, ${ }^{* *} \mathrm{p}<0.05$. STX: syntaxin 1A, ADHD: attention deficit hyperactivity disorder 
$\mathrm{C}$ and $\mathrm{C} / \mathrm{C}$ genotypes were compared with each other, T/C genotype was found statistically significantly higher $(66.7 \%)$ in ADHD group and C/C genotype was found statistically significantly higher $(60.9 \%)$ in the control group $(\mathrm{p}<0.001)$. When $\mathrm{T} / \mathrm{T}$ and $\mathrm{T} / \mathrm{C}$ genotypes were compared with each other, no significant difference was determined ( $\mathrm{p}>0.05$ ).

In the logistic regression analysis, when $\mathrm{T} / \mathrm{T}+\mathrm{T} / \mathrm{C}$ genotype was regarded as reference, the possibility of having $\mathrm{C} / \mathrm{C}$ genotype in the subjects that are not $\mathrm{ADHD}$ is $30 \%$ higher than the subjects diagnosed as ADHD ( $\mathrm{p}<0.001,95 \% \mathrm{CI}$ : $0.178-0.584$ ). The possibility of having $\mathrm{T}$ allele in the subjects diagnosed as ADHD is 2.6 times higher than the subjects that are not ADHD ( $\mathrm{p}<0.001,95 \% \mathrm{CI}$ : 1.667-4.001).

When ADHD subtypes and genotype distribution were compared, T/T and T/C genotypes were found the most often in the predominantly inattentive type (respectively $17.9 \%$ and $64.1 \%$ ) and $\mathrm{C} / \mathrm{C}$ genotype was found the most often in the combined type (36.2\%). There was no significant difference between the subtypes of ADHD ( $p=0.406)$.

\section{DISCUSSION}

The relation between ADHD and SNAP-25 gene, which have a role in the modulation of neurotransmitter releasing together with VAMP2 and syntaxin 1A, was investigated in many studies. A relation between ADHD and (ATTT) $n$ polymorphism in the microsatellite region of SNAP-25 gene was determined. ${ }^{24}$ The studies investigating the relation between ADHD and MnlI and DdeI polymorphisms of SNAP-25 gene have reported different results. Brophy et al. have reported no significant relation between ADHD and MnlI polymorphism, but they have also reported significant relation between ADHD and DdeI polymorphism. ${ }^{7}$ Another study has reported significant relation between ADHD and $\mathrm{MnlI}$ and DdeI polymorphisms of SNAP-25 gene. ${ }^{8}$ In a metaanalysis study, a relation between $\mathrm{ADHD}$ and MnlI polymorphism of SNAP-25 gene was reported. ${ }^{9}$ Recently, a relation between ADHD and SNAP-25 gene is mentioned in the pharmacogenetic studies. In a study performed in spontaneously hypertansive rats, Li et al. ${ }^{25}$ reported that the decreased synthesis of SNAP-25 m-RNA in the prefrontal cortex have recruited after repetitive amphetamine injections. Öner et al. ${ }^{11}$ have reported that hemodynamic changes in the brain induced by methylphenidate might be related with SNAP-25 gene polymorphisms in a Functional Near-Infrared Spectroscopy (fNIRS) study performed with $15 \mathrm{ADHD}$ adults and 16 ADHD children.

VAMP-2 gene has been studied in many psychiatric disorders except ADHD. In a study which the relation of schizophrenia and SNARE proteins are investigated, no relation was reported between schizophrenia and polymorphisms of syntaxin1A, SNAP-25 and VAMP2 genes. ${ }^{12}$ In a study performed among Japan people, the relation of VAMP2 gene rs8067606, rs1061032 and rs 2278637 polymorphisms and the antidepressant response of major depressive patients was investigated and no distinct relation was reported. ${ }^{26}$ In a study performed among patients of bipolar disorder that has a co-morbidity frequency of $9.5 \%$ with $\mathrm{ADHD}$, any distinct relation was not reported between bipolar disorder and VAMP2 gene rs2278637 ve rs8067606 polymorphisms. ${ }^{13,14}$ In a candidate thesis study in Turkey, the relation between the polymorphisms of the genes encoding presynaptic proteins and Alzheimer disease was investigated. ${ }^{27}$ In terms of VAMP2 gene Ins/Del polymorphism, allele distribution was found as follows: $87.5 \%$ Ins allele and $12.5 \%$ Del allele in Alzheimer patients and 79.5\% Ins allele and 20.5\% Del allele in the control group. Also in the same study, Ins/Del genotype was reported to have 0.3 times protective effect for Alzheimer disease. In the present study, allele distributions were similar to the aforementioned study and the possibility of having Ins/Del genotype in the subjects that are not ADHD is $40 \%$ higher than the subjects diagnosed as ADHD. When it is considered that both of the studies are performed among the same ethnic people, it is noteworthy that the similar allele distribution rates of Ins/Del genotype show protective effect for both ADHD and Alzheimer disease. It can also be supposed that this genotype is associated with the symptoms rather than the disorder when it is considered that there are problems in learning, attention and memory in both disorders. In another point of view, it can be suggested that VAMP-2 polymorphism (Ins/Del genotype) can be active on the attention and can be a useful marker to explain the attention deficiency in ADHD and Alzheimer disease.

Moreover, in the present study, in the subjects diagnosed as $\mathrm{ADHD}$, the possibility of having Ins/Ins genotype is 3 times higher and the possibility of having Ins allele is 2 times higher than the subjects that are not ADHD.

Bartl et al. ${ }^{18}$ studied the association of ADHD and MPH, which is used in the treatment of it, and have observed reduction of Syntaxin 1A m-RNA levels and down-regulation at the synaptic proteins following the administration of $\mathrm{MPH}$ and have suggested that these findings show a strong association with extracellular dopamine levels. Binda et al. ${ }^{28}$ studied the association of dopamine and Syntaxin 1A, and reported that while amphetamine did not result in the transport of dopamine out of the cell at the physiologic resting potential $(-60 \mathrm{mV})$ in human DAT cells and dopaminergic neurons, the administration of exogenous Syntaxin 1A to the intracellular compartment resulted in the transport of dopamine out of the cell. In another study performed to investigate the as- 
sociation of Syntaxin 1A and schizophrenia, where dopamine plays an important role in its physiopathology as ADHD, no association was determined between the disorder and exon 3 polymorphism. But, a significant correlation was determined between schizophrenia and intron $7 \mathrm{~T}>\mathrm{C}$ polymorphism, and $\mathrm{C}$ allele was found higher in schizophrenic patients compared to the controls. ${ }^{15}$ In the present study, a significant correlation between Syntaxin 1A gene intron 7 polymorphism and ADHD was determined. Also, the possibility of having $\mathrm{T}$ allele in the subjects diagnosed as ADHD is 2,6 times higher than the subjects that are not ADHD. Nonetheless, the possibility of having $\mathrm{C} / \mathrm{C}$ genotype in the subjects that are not $\mathrm{ADHD}$ is $30 \%$ higher than the subjects diagnosed as ADHD.

As a result, it is supposed that genes encoding presynaptic proteins that have roles in the modulation of neurotransmitter releasing and synaptogenesis play roles in the genetic etiology of ADHD as some of the psychiatric disorders. But considering both the previous studies together with the present study, that which genes are active in which conditions and how much, and what kind of an interaction there is between these genes is still not so clear. To the best of our knowledge, the present study is the first one which investigates the association between ADHD and VAMP 2 gene Ins/ Del polymorphism and Syntaxin $1 \mathrm{~A}$ gene Intron 7 polymorphism in the English literature, and it seems that there may be an association between ADHD and these genes.

Limitations of the study are that the number of the patient and the control groups are not much enough, impossibility of excluding familial genetic load completely, the genes interact with each other besides their relation with the disorder.

As a conclusion, it is supposed that genes encoding synaptic proteins that were analyzed in the present study may also be important in the genetic etiology of ADHD. The present study is supposed to form a base for the forthcoming gene research.

\section{Acknowledgments}

We would like to thank to Dr. Fethullah KENAR for his help in editing English of the manuscript.

\section{REFERENCES}

1. Mick E, Faraone SV. Genetics of attention deficit hyper-activity disorder. Child Adolesc Psychiatr Clin N Am 2008;17:261-284.

2. Rutter M, Silberg J. Gene-environment interplay in relation to emotional and behavioral disturbance. Annu Rev Psychol 2002;53:463-490.

3. Zoroğlu SS, Erdal ME, Alaşehirli B, Erdal N, Sivasli E, Tutkun H et al. Significance of serotonin transporter gene 5-HTTLPR and variable number of tandem repeat polymorphism in attention deficit hyperactivity disorder. Neuropsychobiology 2002;45:176-181.

4. Comings DE, Gade-Andavolu R, Gonzalez N, Wu S, Muhleman D, Blake $\mathrm{H}$, et al. Comparison of the role of dopamine, serotonin and noradrenaline genes in ADHD, ODD and conduct disorder: multivariate regression analysis of 20 genes. Clin Genet 2000;57:178-196.

5. Wilson MC. Coloboma mouse mutant as an animal model of hyperkinesis and attention deficit hyperactivity disorder. Neurosci Biobehav Rev 2000;24:51-57.

6. Kimura K, Mizoguchi A, Ide C. Regulation of growth cone extension by SNARE proteins. J Histochem Cytochem 2003;51:429-433.

7. Brophy K, Hawi Z, Kirley A, Fitzgerald M, Gill M. Synaptosomal-associated protein 25 (SNAP-25) and attention deficit hyperactivity disorder (ADHD): evidence of linkage and association in the Irish population. Mol Psychiatry 2002;7:913-917.

8. Barr CL, Feng Y, Wigg K, Bloom S, Roberts W, Malone M. Identification of DNA variants in the SNAP-25 gene and linkage study of these polymorphisms and attention-deficit hyperactivity disorder. Mol Psychiatry 2000;5:405-409.

9. Faraone SV, Perlis RH, Doyle AE, Smoller JW, Goralnick JJ, Holmgren MA, et al. Molecular genetics of attentiondeficit/hyperactivity disorder. Biol Psychiatry 2005;57:1313-1323.

10. Herken H, Erdal ME, Sengul C, Yucel E, Cakaloz B, Kenar Aİ, et al. Adult attention deficit hyperactivity disorder association with synaptosomal-associated protein (SNAP-25) polymorphisms. Paris, France: 9th World Congress of Biological Psychiatry, June 28-July 2, 2009.

11. Öner Ö, Akın A, Herken H, Erdal ME, Çiftçi K, Ay ME, et al. Association among SNAP-25 Gene DdeI and MnlI polymorphisms and hemodynamic changes during methylphenidate use: a functional nearinfrared spectroscopy study. J Atten Disord 2011;15:628-637.

12. Kawashima K, Kishi T, Ikeda M, Kitajima T, Yamanouchi Y, Kinoshita $\mathrm{Y}$, et al. No association between tagging SNPs of SNARE complex genes (STX1A, VAMP2 and SNAP25) and schizophrenia in a Japanese population. Am J Med Genet B Neuropsychiatr Genet 2008;147B: 1327-1331.

13. Nierenberg AA, Miyahara S, Spencer T, Wisniewski SR, Otto MW, Simon $\mathrm{N}$, et al. Clinical and diagnostic implications of lifetime attentiondeficit/hyperactivity disorder comorbidity in adults with bipolar disorder: data from the first 1000 STEP-BD participants. Biol Psychiatry 2005;57:1467-1473.

14. Abou Jamra R, Gobina CM, Becker T, Georgi A, Schulze TG, Schmael C, et al. Association study between genetic variants at the VAMP2 and VAMP3 loci and bipolar affective disorder. Psychiatr Genet 2008;18: 199-203.

15. Wong AH, Trakalo J, Likhodi O, Yusuf M, Macedo A, Azevedo MH, et al. Association between schizophrenia and the syntaxin 1A gene. Biol Psychiatry 2004;56:24-29.

16. Gabriel SM, Haroutunian V, Powchik P, Honer WG, Davidson M, Davies $\mathrm{P}$, et al. Increased concentrations of presynaptic proteins in the cingulate cortex of subjects with schizophrenia. Arch Gen Psychiatry 1997; 54:559-566.

17. Sokolov BP, Tcherepanov AA, Haroutunian V, Davis KL. Levels of mRNAs encoding synaptic vesicle and synaptic plasma membrane proteins in the temporal cortex of elderly schizophrenic patients. Biol Psychiatry 2000;48:184-196.

18. Bartl J, Link P, Schlosser C, Gerlach M, Schmitt A, Walitza S, et al. Effects of methylphenidate: the cellular point of view. Atten Defic Hyperact Disord 2010; 2:225-232.

19. McCann BS, Schele L, Ward N, Roy-Byrne P. Discriminant validity of the Wender Utah Rating Scale for attention-deficit/hyperactivity disorder in adults. J Neuropsychiatry Clin Neurosci 2000;12:240-245.

20. Oncü B, Olmez S, Sentürk V. Validity and reliability of the Turkish version of the Wender Utah Rating Scale for attention-deficit/hyperactivity disorder in adults. Turk Psikiyatr Derg 2005;16:252-259.

21. Günay Ş, Savran C, Aksoy UM, Maner F, Turgay A, Yargıç İ. The Norm Study, Transliteral Equivalence, Validity, Reliability of Adult Hyperactivity Scale in Turkish Adult Population. Türkiyéde Psikiyatri 2006;8:98-107.

22. Ozkurkcugil A, Aydemir O, Yıldız M, Esen Danacı A, Köroğlu E. Turkish version and reliability of Structured Clinical Interview For DSM-IV Axis I Disorders. Ilac ve Tedavi Dergisi 1999;12:233-236. 
23. Sorias S, Saygilı R, Elbi H, Vahip S, Mete L, Nifirne Z, et al. Structured Clinical Interview for DSM-III-R Personality Disorders (SCID II) (Turkish version). İzmir: Ege Universitesi; 1990.

24. Mill J, Curran S, Kent L, Gould A, Huckett L, Richards S, et al. Association study of a SNAP-25 microsatellite and attention deficit hyperactivity disorder. Am J Med Genet 2002;114:269-271.

25. Li Q, Wong JH, Lu G, Antonio GE, Yeung DK, Nq TB, et al. Gene expression of synaptosomal-associated protein 25 (SNAP-25) in the prefrontal cortex of the spontaneously hypertensive rat (SHR). Biochim Biophys Acta 2009;1792:766-776.

26. Saito S, Takahashi N, Ishihara R, Ikeda M, Suzuki T, Kitajima T, et al.
Association study between vesicle-associated membrane protein 2 gene polymorphisms and fluvoxamine response in Japanese major depressive patients. Neuropsychobiology 2006; 54:226-230.

27. Gökdoğan TE. Investigation of the relationship between the polymorphisms of the genes encoding presynaptic proteins and Alzheimer's disease. Candidate's thesis study. Mersin: Department of Medical Biology and Genetics, School of Medicine, Mersin University; 2009.

28. Binda F, Dipace C, Bowton E, Robertson SD, Lute BJ, Foq JU, et al. Syntaxin $1 \mathrm{~A}$ Interaction with the dopamine transporter promotes amphetamine-induced dopamine efflux. Mol Pharmacol 2008;74:1101-1108 